\title{
ESTABLISHMENT OF IMMORTALIZED PERIODONTAL LIGAMENT PROGENITOR CELL LINE AND ITS BEHAVIOURAL ANALYSIS ON SMOOTH AND ROUGH TITANIUM SURFACES
}

\author{
D. Docheva ${ }^{1, *}$, D. Padula ${ }^{1,2,3}$, C. Popov ${ }^{1}$, P. Weishaupt ${ }^{4}$, M. Prägert ${ }^{1}$, N. Miosge ${ }^{5}$, R. Hickel ${ }^{4}$, W. Böcker ${ }^{1}$, H. Clausen- \\ Schaumann ${ }^{2,3}$, and M. Schieker ${ }^{1}$ \\ ${ }^{1}$ Experimental Surgery and Regenerative Medicine, Department of Surgery, Ludwig-Maximilians-University (LMU), \\ Munich, Germany \\ ${ }^{2}$ Precision- and Micro-Engineering, Engineering Physics, Faculty 06, Munich University of Applied Sciences, \\ Munich, Germany \\ ${ }^{3}$ Center for NanoScience, LMU, Munich, Germany \\ ${ }^{4}$ Department of Restorative Dentistry and Periodontology, Dental School of the LMU, Munich, Germany \\ ${ }^{5}$ Department of Prosthodontics, Georg-August-University of Göttingen, Göttingen, Germany
}

\begin{abstract}
Periodontal ligament (PDL) can be obtained from patients undergoing orthodontic treatment. PDL contains progenitor cells that can be expanded and differentiated towards several mesenchymal lineages in vitro. Furthermore, PDL-derived cells have been shown to generate bone- and PDL-like structures in vivo. Thus, PDL cells, combined with suitable biomaterials, represent a promising tool for periodontitisrelated research and PDL engineering.

Here, a new PDL cell line using lentiviral gene transfer of human telomerase reverse transcriptase (hTERT) was created. HTERT-expressing PDL cells showed similar morphology and population doubling time but an extended lifespan compared to the primary cells. In addition, PDLhTERT cells expressed several characteristic genes and upon osteogenic stimulation produced a calcified matrix in vitro. When cultivated on two topographically different titanium scaffolds (MA and SLA), PDL-hTERT cells exhibited augmented spreading, survival and differentiation on smooth (MA) compared to rough (SLA) surfaces. These findings differ from previously reported osteoblast behaviour, but they are in agreement with the behaviour of chondrocytes and gingival fibroblasts, suggesting a very cell type-specific response to different surface textures.

In summary, we report the testing of titanium biomaterials using a new PDL-hTERT cell line and propose this cell line as a useful model system for periodontitis research and development of novel strategies for PDL engineering.
\end{abstract}

Keywords: Scaffold, titanium, surface topography, periodontal ligament, progenitor cell, biocompatibility, osteogenic differentiation.

*Address for correspondence:

Denitsa Docheva

Laboratory for Experimental Surgery and Regenerative Medicine

Department of Surgery, LMU

Nussbaumstr. 20, D-80336 Munich, Germany

Telephone Number: +49 8951605486

FAX Number: +49 8951605489

E-mail: denitsa.docheva@med.uni-muenchen.de

\section{Introduction}

Periodontal ligament (PDL) tissue anchors the tooth root to the alveolar bone of the jaw and plays an important role in tooth maintenance, tooth mobility, cementum formation as well as in tissue defence against inflammation (Parlar et al., 2005). Infection-triggered diseases, such as periodontitis, can result in PDL destruction and subsequently, in tooth loss. One of the most attractive and up-to-date approaches for tissue regeneration is cell-based tissue engineering which relies on the combination of reparative cells and biocompatible scaffolds (Docheva et al., 2007).

In recent years, several groups have reported that PDL contains endogenous stem and progenitor cells ( Ivanovski et al., 2006; Bluteau et al., 2008). These cells share a number of characteristics with the bone marrow-derived mesenchymal stem cells (MSC). For example, both cell types have similar expression of surface antigens (e.g., STRO-1, CD73, CD90, CD105 and etc.) and osteoblastrelated genes (Runx 2, alkaline phosphatase, osteonectin, etc.), and can differentiate into osteoblasts, adipocytes and chondrocytes in vitro (Shi et al., 2005; Docheva et al., 2008; Fujii et al., 2008; Tomokiyo et al., 2008). However, PDL cells have some specific features such as tendonrelated gene expression (Scleraxis and tenomodulin) and furthermore, can form PDL-like structures upon transplantation in vivo (Seo et al., 2004; Fujii et al., 2008; Itaya et al., 2009).

Due to their regenerative potential but limited life span in vitro, PDL-derived cells have been isolated and immortalized independently by several groups ( Fujita et al., 2005; Pi et al., 2007; Fujii et al., 2008; Tomokiyo et al., 2008). Our group has recently described the use of a lentiviral gene transfer of human telomerase reverse transcriptase (hTERT) in human MSC. The obtained hTERT-expressing cell line (SCP-1) did not show changes in the karyotype and the expression of tumour suppressor genes, nor tumour formation in vivo (Böcker et al., 2008).

The purpose of this study was firstly, to create a PDLderived cell line via stable, lentivirus-based hTERT overexpression; secondly, to characterize the PDL-hTERT cells by long-term proliferation analysis, expression of several characteristic genes and in vitro osteogenic differentiation; and thirdly, with regards to upcoming PDL 
engineering, to investigate what kind of surface topography is optimal for this cell type. Therefore, PDL-hTERT cells were cultivated on two different scaffold textures, machined (MA) and sandblasted/acid-etched (SLA) titanium, and their cell spreading, survival and matrix calcification were evaluated.

\section{Materials and Methods}

\section{Titanium scaffolds}

MA and SLA titanium disks (with a diameter of $15 \mathrm{~mm}$ and a thickness of $1 \mathrm{~mm}$ ) were manufactured from commercially pure grade 2 titanium (Straumann, Basel, Switzerland). The MA scaffolds did not receive any surface treatment. The SLA scaffolds were produced as described in (Rupp et al., 2006): first, macro-roughening by sandblasting with a large grid $(250-500 \mu \mathrm{m})$ and secondly, micro-roughening by acid-etching with $\mathrm{HCl} / \mathrm{H}_{2} \mathrm{SO}_{4}$.

\section{Surface topography analysis}

For estimation of surface roughness, the three dimensional (3D) areal surface roughness parameters were calculated according to:

(a) average roughness $(\mathrm{Sa})$

$$
S_{a}=\frac{1}{n} \sum_{i}\left|z_{i}\right|
$$

(b) root mean squared roughness (RMS roughness, Sq, $\mathrm{S}_{\mathrm{RMS}}$ )

$$
S_{q}=S_{R M S}=\sqrt{\frac{1}{n} \sum_{i} Z_{i}^{2}}
$$

(c) peak-to-valley height $(\mathrm{St})$

$$
S_{t}=\max _{i} Z_{i}-\max _{j} Z_{j}
$$

In the above formulae $z_{i}$ denotes the vertical deviation of point $i$ from the mean plane and the sum includes all data points of the area (cf. also ISO 25178).

Confocal white-light and bright-field images were taken on a PL $\mu 2300$ confocal microscope with blue lightemitting diode (LED) light source (Schaefer Technology, Langen, Germany). Peak-to-valley height $\left(\mathrm{S}_{\mathrm{t}}\right)$ and RMS roughness $\left(\mathrm{S}_{\mathrm{q}}\right)$ were automatically calculated using the $\mathrm{PL} \mu$ confocal software2.31. Atomic force microscopy (AFM) measurements were carried out using a NanoWizard AFM (JPK Instruments, Berlin, Germany). Silicone-nitride cantilevers with a pyramidal tip (Veeco Instruments, Mannheim, Germany) were used for MA and silicon cantilevers with $3.6 \mu \mathrm{m}$ high-density carbon needle (Nanotools, Munich, Germany) were used for SLA. MA and SLA scaffolds were scanned in contact and tapping mode, respectively. The MA surface was imaged with $1024 \times 1024$ pixels $^{2}$ resolution at line rates of $0.5-19 \mathrm{~Hz}$ whereas the SLA surface was imaged with $512 \times 512$ pixels $^{2}$ resolution at line rates of $0.1 \mathrm{~Hz}$. Peak-to-valley height $\left(\mathrm{S}_{\mathrm{t}}\right)$ was calculated on the whole images whereas lateral peak-to-peak distances were calculated from cross-sections using JPK image processing software version 3 . Three independent scans per scaffold type were used for the calculations.

\section{Cell isolation and cultivation}

The experimental protocol was approved by the Ethical Commission of the Medical Faculty of the LMU (Project: 376-06 and 166-08). PDL tissues were obtained from one healthy individual $(<25$ years) undergoing tooth extraction of the two first upper premolars due to orthodontic reasons. Briefly, the tissues from the middle third of the teeth were scraped with a scalpel under sterile conditions and seeded in culture flasks. In a period of 7 days, cells migrated actively out of the tissues. The PDL-derived cells were cultured in Dulbecco's minimal essential medium (DMEM) high glucose (PAA, Pasching, Austria), 10\% foetal bovine serum (FBS) (Sigma-Aldrich, Munich, Germany) and 1\% penicillin/streptomycin (PAA). SCP-1 cells (Böcker et al., 2008) were grown in MEM Alpha culture medium supplemented with GlutaMAX (Gibco, Karslruhe, Germany), 10\% FBS and 1\% penicillin/ streptomycin.

\section{Virus production and infection}

Lentivirus, expressing hTERT, was produced as described in (Böcker et al., 2008). PDL cells were infected at passage one with the hTERT lentivirus (Multiplicity Of Infection (MOI): $5 \times 10^{4}$ ) and selected with $10 \mu \mathrm{g} / \mathrm{ml}$ blasticidin for seven days.

\section{Growth kinetics}

Long-term cell growth was evaluated by calculation of cumulative population doubling (PD) (Huang et al., 2006). $\mathrm{PD}$ time was determined from three consecutive passages (PDL and PDL-hTERT in passage 6-8 and SCP-1 in passage 70-72). The calculation of SCP-1 PD time was based on the growth curve published by Böcker et al. (2008).

\section{Flow cytometry (FACS)}

Phycoerythrin (PE)- or fluorescein isothiocyanate (FITC)coupled primary antibodies against human CD13 (PE), CD29 (FITC), CD44 (FITC), CD45 (FITC), CD73 (PE), CD90 (FITC) and CD105 (FITC) (BD Pharmingen, Heidelberg, Germany) were applied. Cultured PDL-hTERT cells $\left(1 \times 10^{5}\right.$ cells $)$ were incubated with $100 \mu \mathrm{l}$ PBS containing $1 \mu \mathrm{l}$ primary antibody for 1 hour. After two washing steps with PBS, cells were scanned on a FACScan machine (Becton Dickinson, Mountain View, CA, USA). At least $1 \times 10^{4}$ cells were analyzed using WinMDI software version 2.9 (http://facs.scripps.edu/software.html). Three independent flow cytometry experiments were performed with PDL-hTERT cells in 58-66 PD.

\section{PCR}

RNA from PDL (13 PD), PDL-hTERT (13 PD) and SCP1 (106 PD) cells was extracted with RNeasy Mini Kit (Qiagen, Hilden, Germany). RNA from tendon and bone tissue was isolated with RNeasy Midi Kit (Qiagen). Copy DNA was synthesised using AMV First-Strand cDNA Synthesis Kit (Invitrogen, Karlsruhe, Germany). The cDNA was diluted $1: 10$ and $1 \mu$ was used as a PCR template. PCR was performed with Taq DNA Polymerase (Invitrogen) in a PTC-200 Thermal Cycler (Bio-Rad Laboratories, München, Germany). The primer pairs for 
Table 1. Primer pairs and PCR conditions.

\begin{tabular}{|c|c|c|c|c|c|}
\hline Target gene & Primers & $\begin{array}{l}\text { Annealing } \\
\text { temperature }\end{array}$ & $\begin{array}{l}\text { Cycle } \\
\text { numbers }\end{array}$ & Product size & Reference \\
\hline hTERT & $\begin{array}{l}\text { F 5'-ctacggcgacatggagaac-3' } \\
\text { R 5'-gacacttcagccgcaagac-3' }\end{array}$ & $54{ }^{\circ} \mathrm{C}$ & 35 & $413 \mathrm{bp}$ & (Sarin et al., 2005) \\
\hline Scleraxis & $\begin{array}{l}\text { F 5'-cctgaacatctgggaaatttaattttac-3' } \\
\text { R 5'-cgc caaggcacctcctt-3' }\end{array}$ & $48^{\circ} \mathrm{C}$ & 39 & $111 \mathrm{bp}$ & $\begin{array}{l}\text { (Schulze-Tanzil et } \\
\text { al., 2004) }\end{array}$ \\
\hline Tenomodulin & $\begin{array}{l}\text { F 5'-ggatacactggcatctacttcg-3' } \\
\text { R 5'-gtgacgggtcttctctactttc-3' }\end{array}$ & $48^{\circ} \mathrm{C}$ & 39 & $381 \mathrm{bp}$ & self-designed \\
\hline Tenascin $\mathrm{C}$ & $\begin{array}{l}\text { F 5'-gagaaag gcagacacaagag-3' } \\
\text { R 5'-gcagtccagttgagtttgag-3' }\end{array}$ & $57^{\circ} \mathrm{C}$ & 35 & $395 \mathrm{bp}$ & self-designed \\
\hline Runx 2 & $\begin{array}{l}\text { F 5'-cactatccagccacctttac-3' } \\
\text { R 5'-atcagcgtcaacatc-3' }\end{array}$ & $55^{\circ} \mathrm{C}$ & 35 & $315 \mathrm{bp}$ & self-designed \\
\hline BSP & $\begin{array}{l}\text { F 5'-catagccatcgtagcettgtcct-3' } \\
\text { R 5'-ctatggagaggacgccacgectgg-3' }\end{array}$ & $55^{\circ} \mathrm{C}$ & 35 & $587 \mathrm{bp}$ & $\begin{array}{l}\text { (Gronthos et al., } \\
\text { 2000) }\end{array}$ \\
\hline Collagen 1 & $\begin{array}{l}\text { F 5'-cgtgaccaaaaaccaaaagtgc-3' } \\
\text { R 5'-ggggtggagaaaggaacagaaa-3' }\end{array}$ & $54^{\circ} \mathrm{C}$ & 40 & $186 \mathrm{bp}$ & $\begin{array}{l}\text { (Provenzano et al., } \\
\text { 2005) }\end{array}$ \\
\hline Collagen 3 & $\begin{array}{l}\text { F 5'-cccactattattttggcacaacag-3' } \\
\text { R 5'-gcatggttctggcttccaga-3' }\end{array}$ & $48^{\circ} \mathrm{C}$ & 39 & $99 \mathrm{bp}$ & $\begin{array}{l}\text { (Shigeyama et al., } \\
\text { 2005) }\end{array}$ \\
\hline GAPDH & $\begin{array}{l}\text { F 5'-caactacatggtttacatgttc-3' } \\
\text { R 5'-gccagtggactccacgac-3' }\end{array}$ & $50{ }^{\circ} \mathrm{C}$ & 30 & $181 \mathrm{bp}$ & $\begin{array}{l}\text { (Takahashi et al., } \\
\text { 2003) }\end{array}$ \\
\hline
\end{tabular}

$\mathrm{F}$ - forward primer; $\mathrm{R}$ - reverse primer

selected genes as well as the PCR conditions used in this study are listed in table 1. PCR results were reproduced three times.

\section{Osteogenic differentiation}

Osteogenic differentiation of PDL and PDL-hTERT cells was assessed according to (Böcker et al., 2007; Böcker et al., 2008). Briefly, $4 \times 10^{3}$ cells $/ \mathrm{cm}^{2}$ were seeded and cultivated in osteogenic medium composed of DMEM high glucose, 10\% FBS, $10 \mathrm{mM} \beta$-glycerophosphate, $50 \mu \mathrm{M}$ L-ascorbic acid 2-phosphate, $100 \mathrm{nM}$ dexamethasone, and $1 \%$ penicillin/streptomycin. The medium was changed twice per week for a period of 21 days. The extent of osteogenic differentiation was determined by Alzarin Red staining. After fixation with $10 \%$ formaldehyde, the cells were stained with 40 mM Alzarin Red S dye $\mathrm{pH} 4.1$ (SigmaAldrich) for $20 \mathrm{~min}$, rinsed with distilled $\mathrm{H}_{2} \mathrm{O}$ and photographed with Axiocam ICc3 camera (Carl Zeiss, Göttingen, Germany) on Axiovert S100 inverted microscope. For the Alizarin Red quantification, Osteogenesis Quantification Kit (Millipore, Bedford, USA) was used. The amount of extracted Alizarin Red dye was measured on a microtiter plate reader (Microtek, Overath, Germany) at $405 \mathrm{~nm}$ and quantified against an Alizarin Red standard curve. PDL cells were differentiated twice (13 and $16 \mathrm{PD}$ ), PDL-hTERT cells were differentiated thrice on plastic (13, 16 and 75 PD) and twice on MA and SLA scaffolds (82 PD).

\section{Cytochemistry}

For investigation of hTERT expression, PDL-hTERT and SCP-1 cells (positive control) were stained with antihTERT primary antibody (CalBiochem, Darmstadt, Germany) as described by (Böcker et al., 2008). PDLhTERT were stained independently twice (13 PD and 24 PD). For investigation of cell morphology and actin architecture, PDL-hTERT cells (18 PD) were grown on MA and SLA ( $1 \times 10^{4}$ cells/scaffold) for 3 days and after 
4\% PFA fixation the cells were consecutively incubated with cytoskeleton dye $(0.5 \mu \mathrm{M}$ Alexa Flour 488-labelled phalloidin $)$, membrane dye $(15 \mu \mathrm{g} / \mathrm{ml}$ concanavalin A) and DAPI (all Invitrogen). For investigation of cell growth, PDL-hTERT cells (18 PD) were cultured on MA and SLA ( $4 \times 10^{3}$ cells/scaffold) for 1,3 and 9 days, fixed with $4 \%$ PFA and stained with DAPI. The scaffold surfaces were photographically reconstructed (100 consecutive images, covering surface area of $141.37 \mathrm{~mm}^{2}$ ) using the automated 'MosaiX' tool of the AxioVision Rel software version 4.6 (CarlZeis). The number of cell nuclei was counted using the 'Analyse Particle' tool of Image-Pro Plus software version 4 (Media Cybernetics, Bethesda, MD, USA). For investigation of cell death (live-dead assay), PDL-hTERT cells (18 PD) were grown on MA and SLA for 1, 9 and 21 days, and were then incubated with staining mixture of 10 $\mu \mathrm{g} / \mathrm{ml}$ fluorescein-diacetate (FDA) and $500 \mu \mathrm{g} / \mathrm{ml}$ propidium iodide (PI) (both Sigma-Aldrich) for $1 \mathrm{~min}$. After brief washing with phosphate-buffered saline (PBS), five pictures (10x magnification) were taken for each scaffold. The number of green (FDA-positive, live cells) and red cells (PI-positive, dead cells) was manually counted and the cell death was presented in percentage for day 1 and 9 , and as PI-positive cells $/ \mathrm{mm}^{2}$ for day 21 . For detection of mitochondrial depolymerisation, JC-1 $\left(5,5^{\prime}, 6,6^{\prime}\right.$-tetrachloro-1,1',3,3' -tetraethylbenzimidazolylcarbocyanine iodide) staining was used. PDL-hTERT cells were grown for 9 days on MA and SLA, incubated with $3 \mu \mathrm{g} / \mathrm{ml} \mathrm{JC}-1$ and $1 \mu \mathrm{g} / \mathrm{ml}$ Hoechst 33342 (both Invitrogen) diluted in complete cell culture media for $30 \mathrm{~min}$ at $37^{\circ} \mathrm{C} / 5 \% \mathrm{CO}$, washed with $\mathrm{PBS}$ and pictured using AxioCam MRm camera (Carl Zeiss). JC-1 labels viable cells in red (aggregates in mitochondria and emits $590 \mathrm{~nm}$ ) and apoptotic cells in green/yellow (monomer in cytosol and emits $514 \mathrm{~nm}$ ). Two independent scaffold seedings were used in the above analyses. The microscopy was carried out on Axioskope 2, Axiovert S100 200 microscopes equipped with Axiocam MRm camera (Carl Zeiss) or ORCA-AG camera (Hamamatsu Photonics, Herrsching, Germany).

\section{WST-1 cell proliferation assay}

PDL-hTERT cells ( $4 \times 10^{3}$ cells/scaffold) were grown for 9 days on MA and SLA and then incubated with $50 \mu \mathrm{l} /$ well WST- 1 reagent for $4 \mathrm{~h}$ at $37^{\circ} \mathrm{C} / 5 \% \mathrm{CO}_{2}$. The supernatant was collected and the absorbance of the samples was measured against a background control (just reagent) on a microtiter plate reader (Microtek) using $450 \mathrm{~nm}$ and 620 $\mathrm{nm}$ reference filters. WST-1 reagent is cleaved by cellular enzymes to formazan dye and the amount of dye correlates to the number of metabolically active cells. The experiment was performed twice.

\section{Statistics}

Quantitative data and statistical analyses were processed with SigmaPlot8 and SigmaStat3 (Systat software, Erkrath, Germany). Means and standard deviations (S.D.) are illustrated in the figures. Student's $t$ and Duncan's tests were used for pairwise significances and multiple comparisons, respectively. A value of $p<0.05$ was considered significant.

\section{Results}

Topographical comparison of MA and SLA scaffolds First, by bright-field and white-light confocal microscopy (Fig. 1a-c), an overview of approx. 140x105 $\mu^{2}$ area and a $3 \mathrm{D}$ reconstruction were obtained for each scaffold. The average peak-to-valley height $\left(\mathrm{S}_{\mathrm{t}}\right)$ of MA was $\mathrm{S}_{\mathrm{t}}=2.8 \pm$ $0.9 \mu \mathrm{m}$ whereas of SLA $-\mathrm{S}_{\mathrm{t}}=36.1 \pm 5.8 \mu \mathrm{m}$ (Fig. 1d). Since the two scaffold types displayed very different topography, the areal RMS roughness $\left(\mathrm{S}_{\mathrm{q}}\right)$ was calculated and it was found that the SLA was 28 -fold rougher $\left(\mathrm{S}_{\mathrm{q}}=\right.$ $4.9 \pm 0.5 \mu \mathrm{m})$ than the MA $\left(\mathrm{S}_{\mathrm{q}}=0.2 \pm 0.01 \mu \mathrm{m}\right)($ Fig. 1e). Next, a 'zoomed in' view of each surface was obtained by AFM analysis. Representative images of 10x10 $\mu^{2}$ scaffold areas and height profiles of MA and SLA surfaces are shown in Fig. 2a and 2b, respectively. On the MA surface, the peaks were evenly distributed while the SLA exhibited very irregular micro-wrinkles. Based on AFM images, the peak-to-valley height $\left(\mathrm{S}_{\mathrm{t}}\right)$ was calculated for three different $10 \times 10 \mu \mathrm{m}^{2}$ areas per scaffold (Fig. 2c). The average peak-to-valley height of the MA scaffold was $\mathrm{S}_{\mathrm{t}}=$ $0.9 \pm 0.3 \mu \mathrm{m}$ while of the SLA $\mathrm{S}_{\mathrm{t}}=6.4 \pm 1.6 \mu \mathrm{m}$. Finally, the average distance between peaks was determined using the cross-sectional profiles (Fig. 2d). On MA, the average lateral peak-to-peak distance was $2.4 \pm 0.3 \mu \mathrm{m}$, whereas on SLA it was $4.9 \pm 1.9 \mu \mathrm{m}$.

\section{Generation and characterization of PDL-hTERT cells}

After short in vitro expansion, the primary PDL cells were infected with hTERT-lentivirus (Fig. 3a) and a homogeneous PDL-hTERT cell population was obtained by blasticidin selection. The hTERT-transgene overexpression was firstly proved by PCR. The primary PDL cells showed no hTERT signal at 13 PD while abundant expression of the hTERT-transgene was detected in PDL-hTERT and SCP-1 cells (positive control) (Fig. $3 b)$. Secondly, using immunocytochemistry, we could demonstrate hTERT protein expression and nuclear localization (Fig. 3c).

PDL-hTERT cells exhibited, similar to the primary PDL cells, spindle-like cell morphology which was preserved throughout the continuous passaging (Fig. 4a). The growth capacity of PDL and PDL-hTERT cells was investigated by calculating the cumulative PD for approx. one year. As shown in Fig. 4b, PDL cells underwent a 'plateau' phase after 25 PD whereas PDL-hTERT remained proliferative. Based on the PD data, the PD time of PDL and PDLhTERT cells was estimated and compared to SCP-1 cells (Fig. 4c). The results demonstrated that PDL cells had a 2.4-fold slower division rate than SCP-1, but also that the presence of hTERT-transgene did not significantly alter PDL-hTERT cell proliferation.

PDL primary cells have been reported to possess ligament- and MSC-like characteristics. Therefore, we investigated whether hTERT-transduced PDL cells meet the same criteria by performing FACS analysis for several surface antigens. More than $92 \%$ of PDL-hTERT cells expressed MSC markers such as CD73, CD90 and CD105 but only $4.7 \%$ were positive for CD44. In addition, PDLhTERT cells expressed CD13 and CD29, proteins that have 
MA

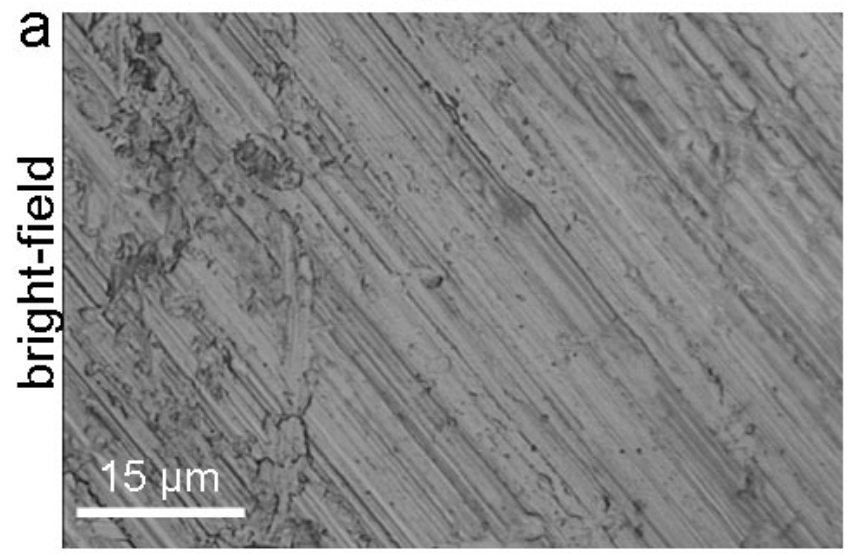

b
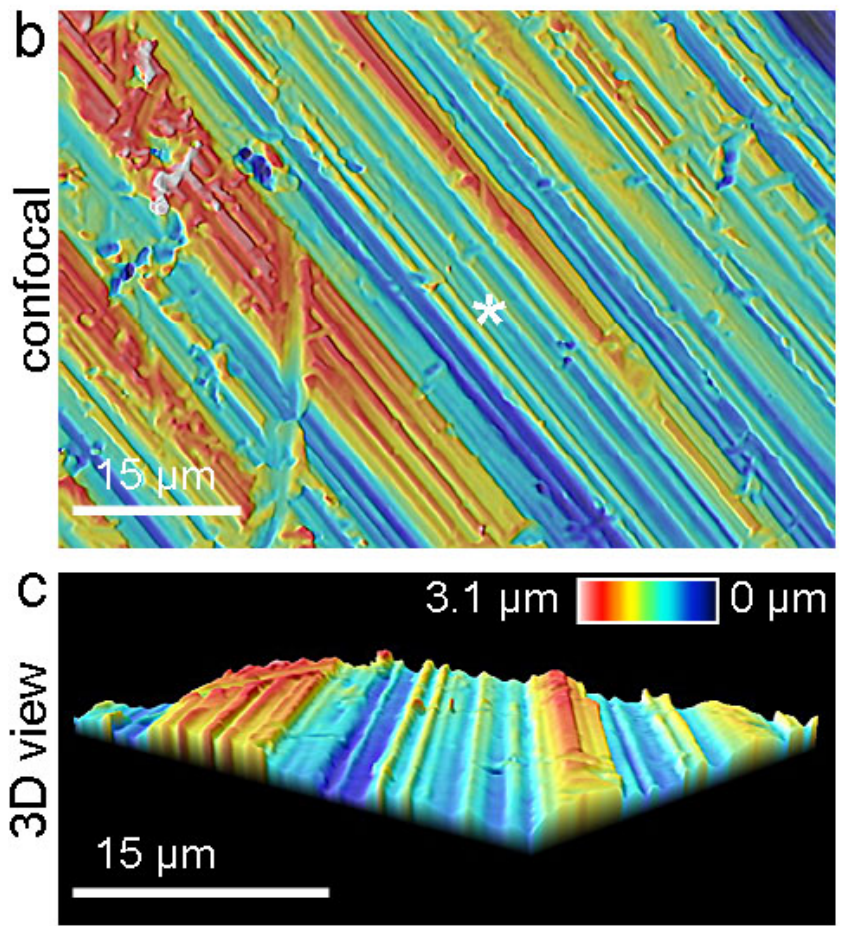

d

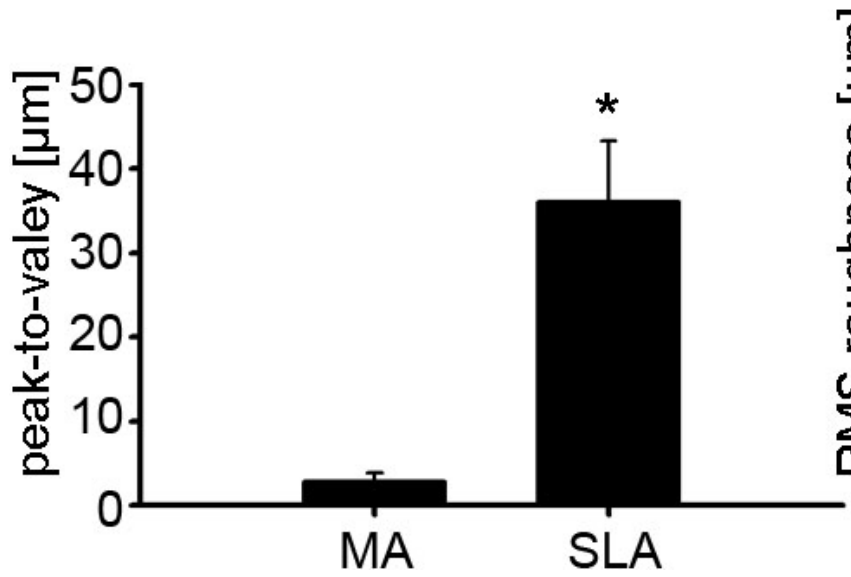

SLA
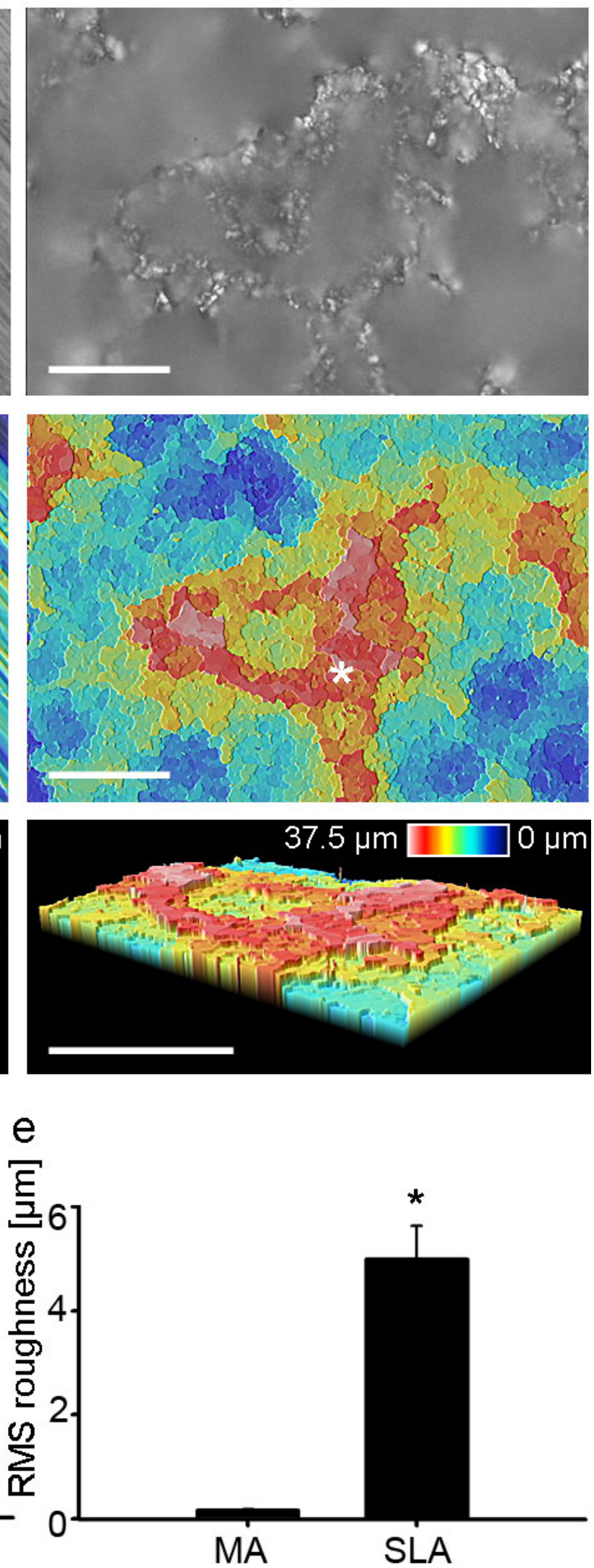

Fig. 1. Bright-field (a), confocal white-light (b) and 3D-reconstructed (c) micrographs of MA and SLA scaffolds. (d) Peak-to-valley height $\left(\mathrm{S}_{\mathrm{t}}\right)$ and (e) RMS roughness $\left(\mathrm{S}_{\mathrm{q}}\right)$. SLA has significantly higher peaks $(p=0.0013)$ and rougher surface $(p=0.0002)$. Three independent scans for each scaffold type were used in the calculations. 


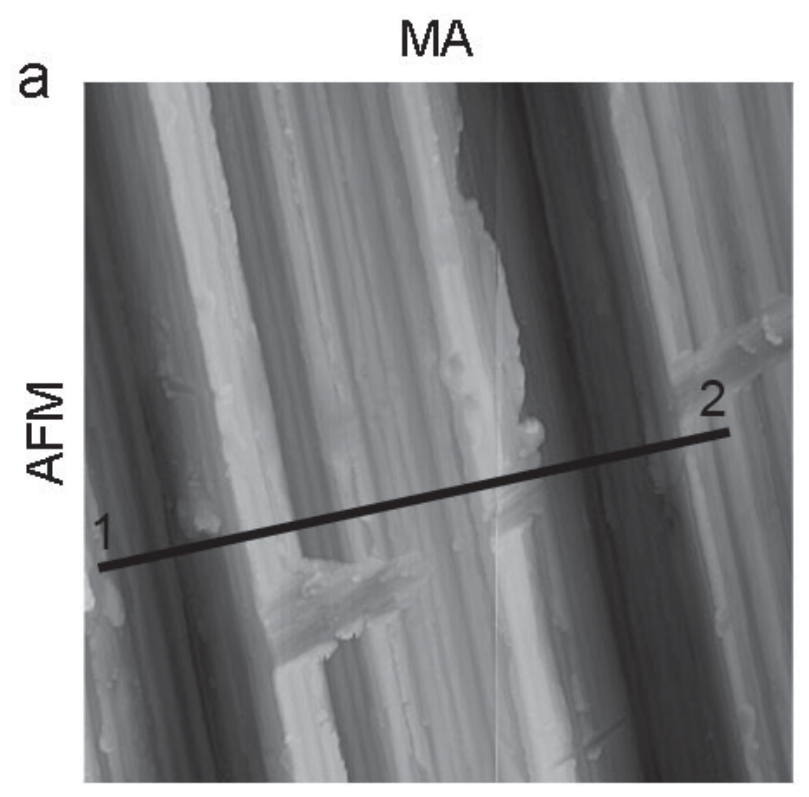

\section{SLA}

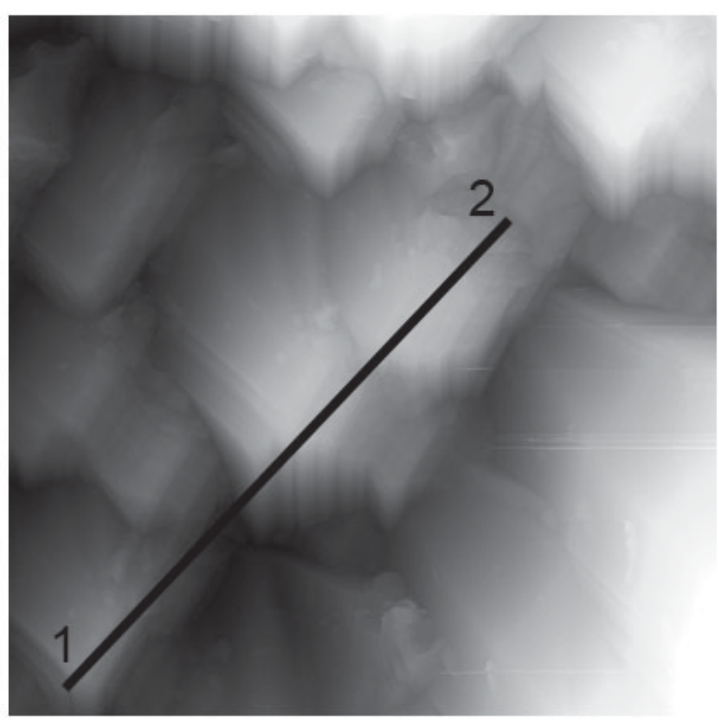

b

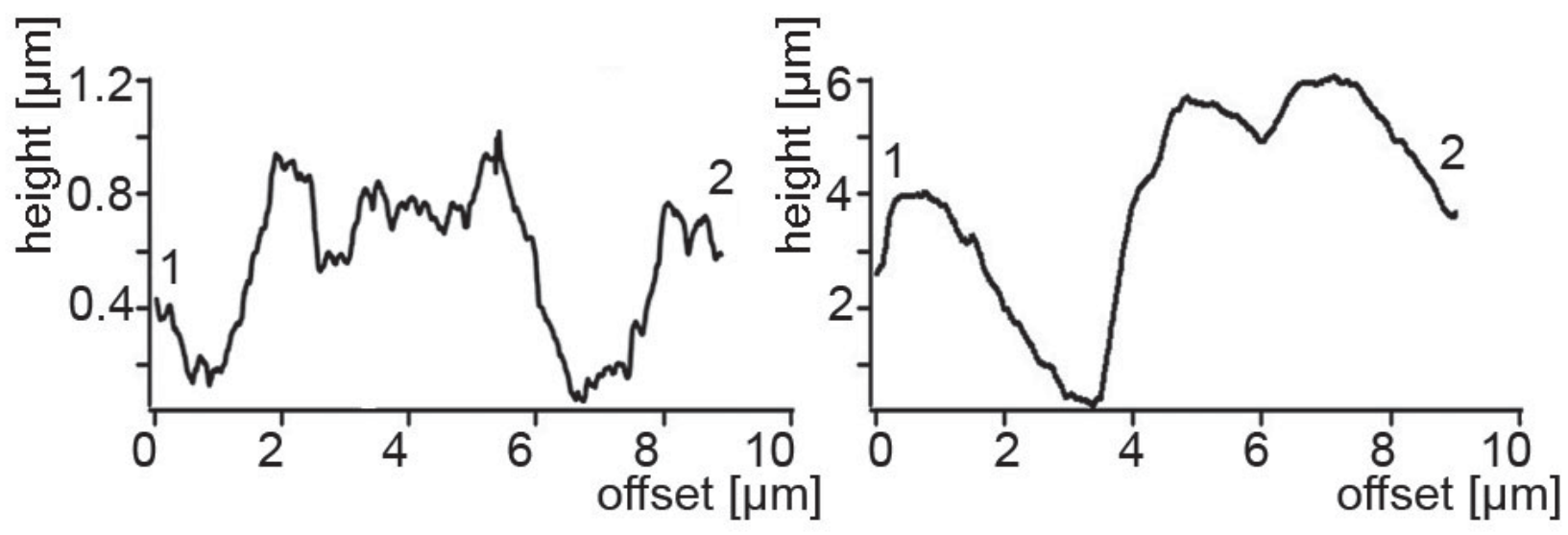

C

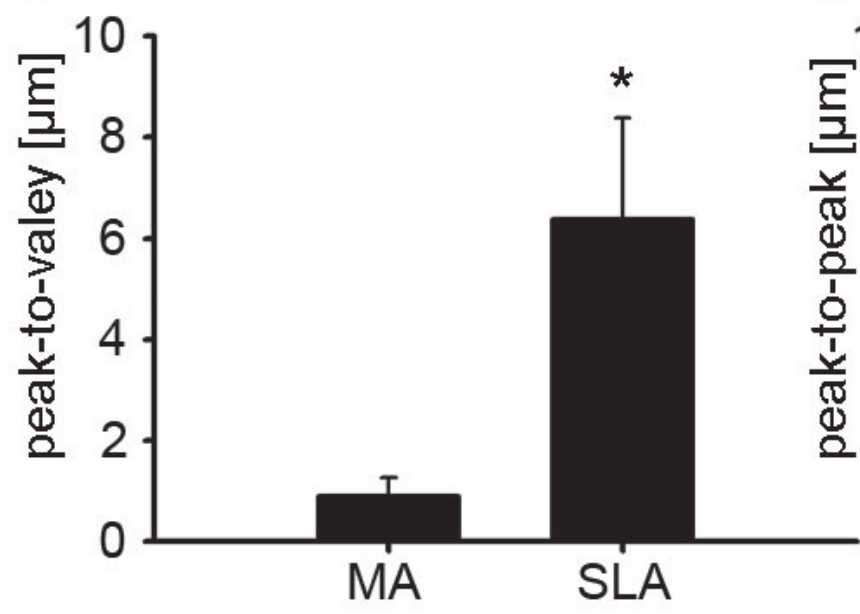

d

Fig. 2. AFM micrographs of MA and SLA (a). (b) Cross-sectional profiles along the black lines that are inserted in (a). (c) Peak-to-valley height $\left(\mathrm{S}_{\mathrm{t}}\right)$. SLA micro-wrinkles are significantly higher than all peaks in MA $(p=0.0094)$. (d) Average lateral peak-to-peak distances. In comparison to SLA, MA peaks are very regularly distributed. Average values from three independent images/scaffold were used. 
a

\begin{tabular}{|l|l|l|l|l|l|l|l|l|}
\hline$P_{\text {RSV }} / 5^{\prime}$ LTR & $\psi$ & RRE & P $_{\text {CMV }}$ & hTERT & P SV40 & EM7 & BSD & $\triangle U 3 / 3^{\prime}$ LTR \\
\hline
\end{tabular}

b

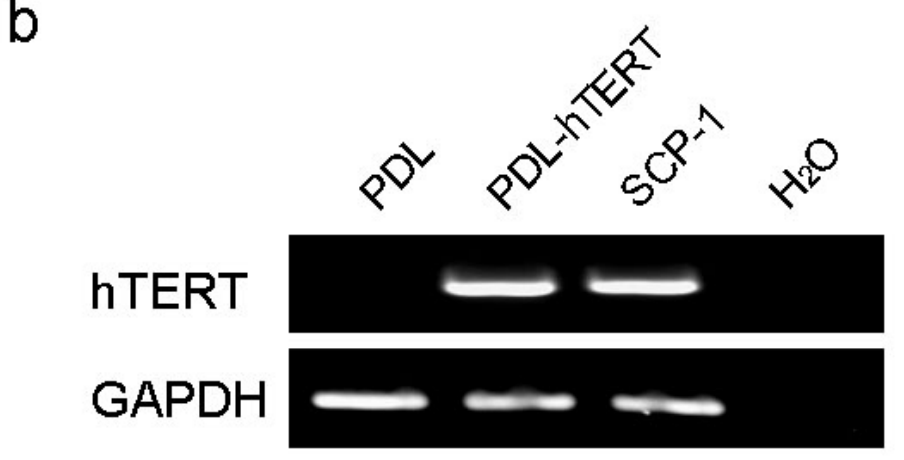

C

PDL-hTERT

(24 PD)
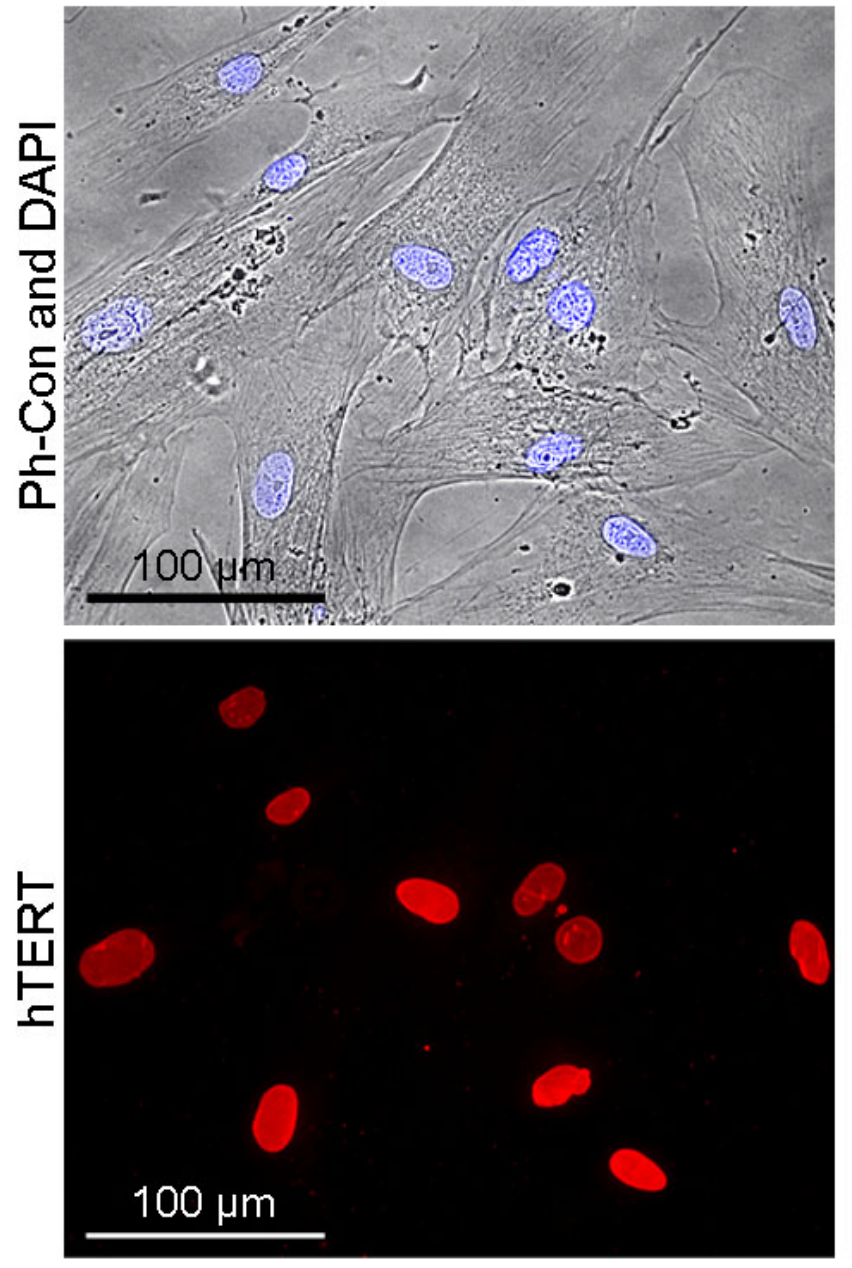

positive control: SCP-1

(134 PD)
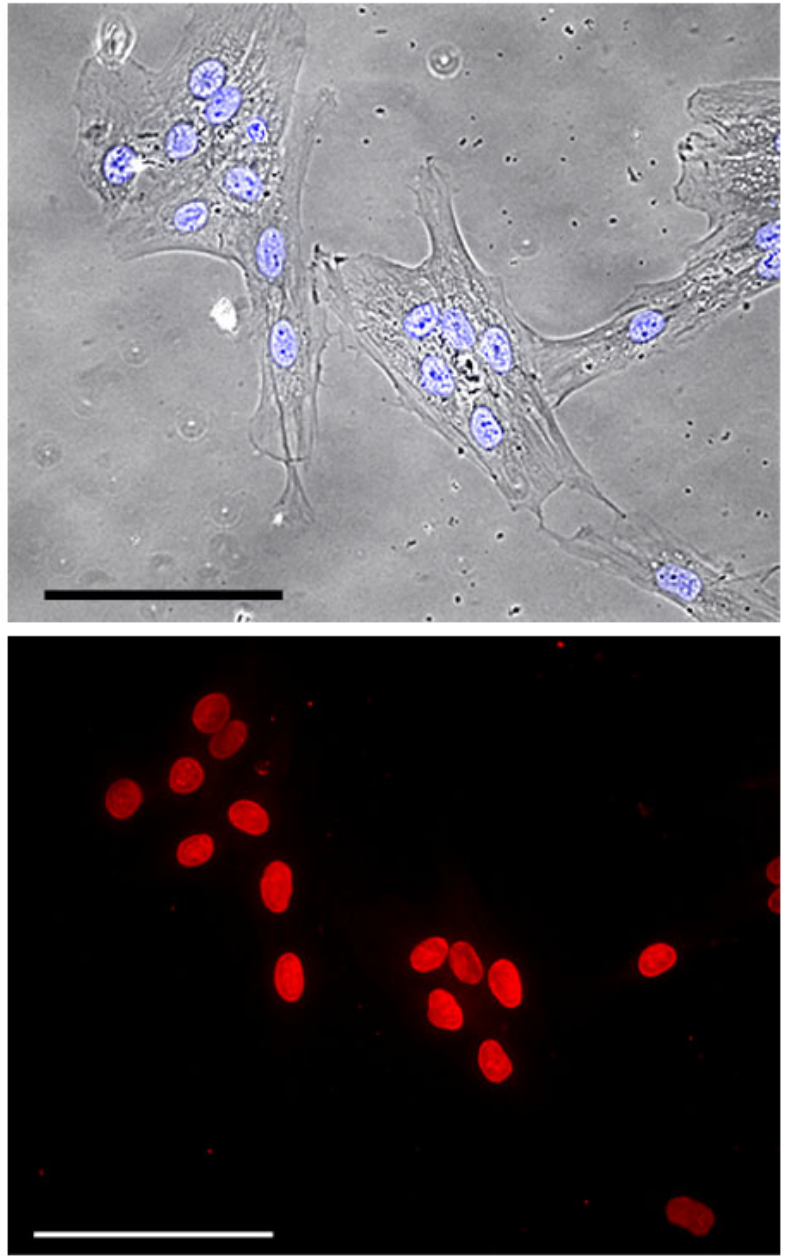

Fig. 3. HTERT-overexpression in PDL cells. (a) A scheme of the lentiviral expression construct (pLenti6/v5-hTERT). Abbreviations: P - promoter; LTR - long terminal repeat; $\Psi$ - HIV-1 packaging signal, RRE - HIV-1 Rev responsive element; hTERT - human telomerase reverse transcriptase cDNA; BSD - blasticidin gene. (b) PCR analyses revealed strong hTERT expression in PDL-hTERT and SCP-1 (positive control) cells. (c) Immunocytochemistry showed hTERT localization in the nuclei of all analysed cell PDL-hTERT cells. Upper panels - phase-contrast (Ph-Con) and nuclear staining (DAPI); lower panels hTERT staining. 
a

PDL (16 PD)

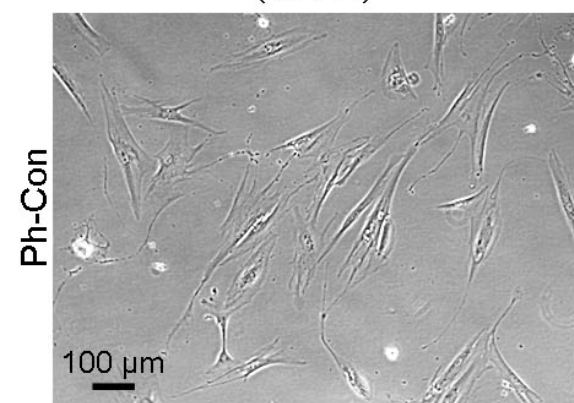

b

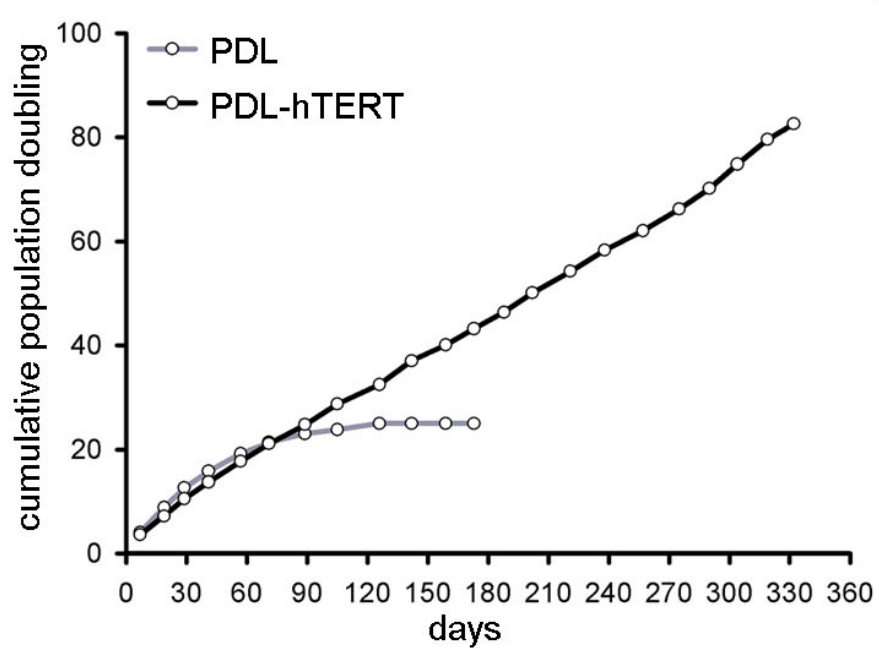

(16 PD)
PDL-hTERT

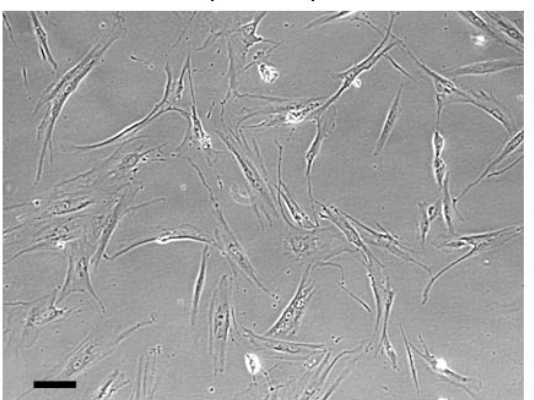

C

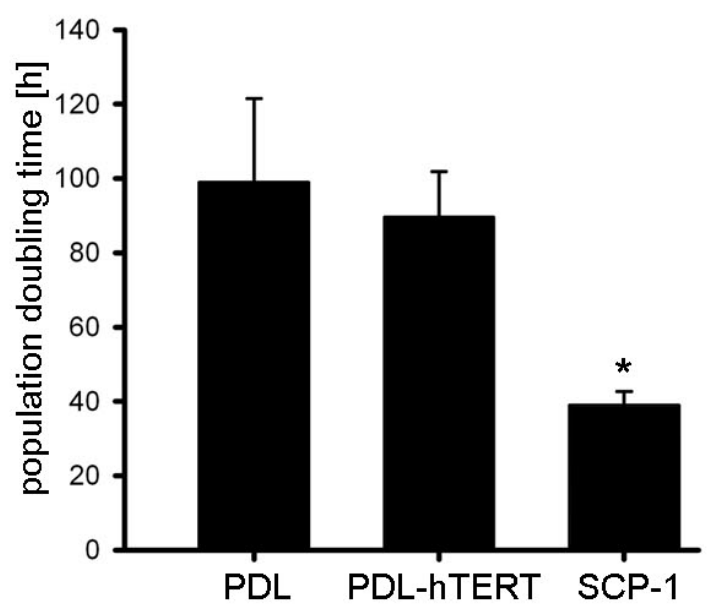

PDL-hTERT

(82 PD)
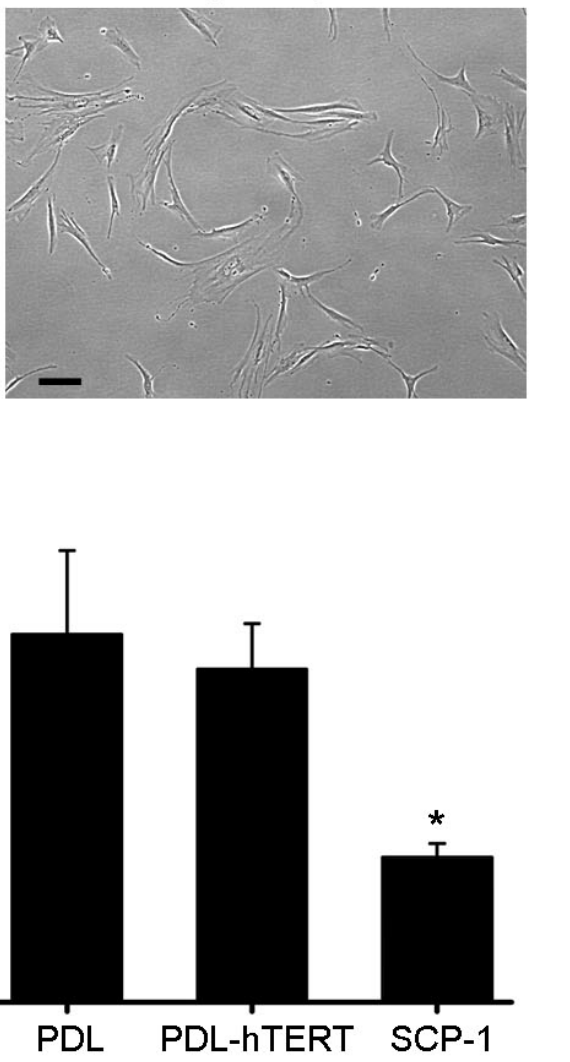

Fig. 4. Cell morphology (a) and growth curves (b) of PDL and PDL-hTERT cells. PDL cells entered senescence after 25 PD while PDL-hTERT doubled 82 times in the monitored period of 332 days. (c) Calculation of PD time shows that primary and hTERT-transduced PDL cells divide similarly but significantly slower than SCP-1 cells ( $p<$ 0.05). Counts from three consecutive passages were used for these calculations.

a

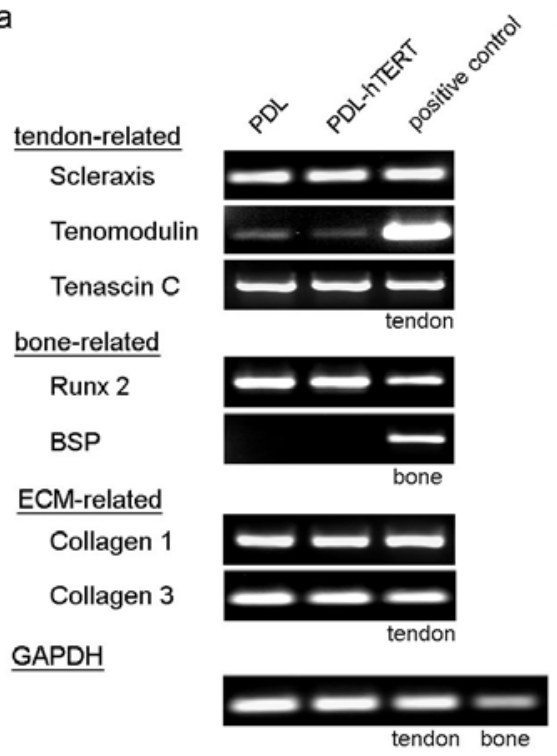

b

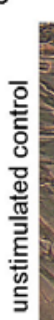

PDL (16 PD)
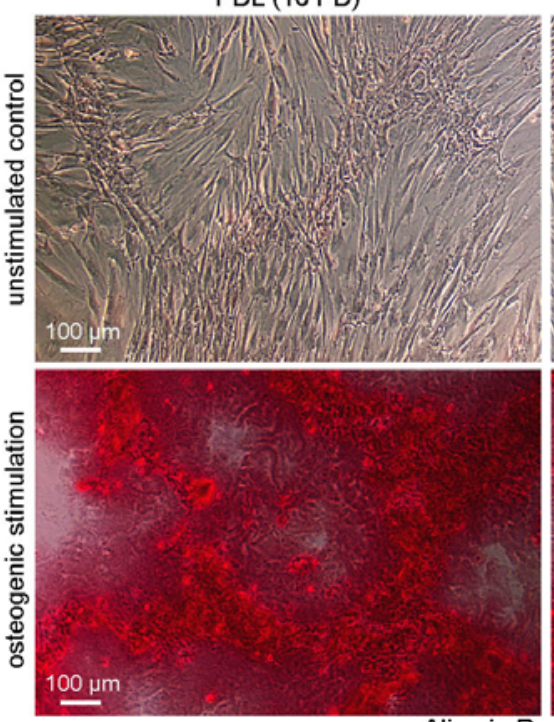
a

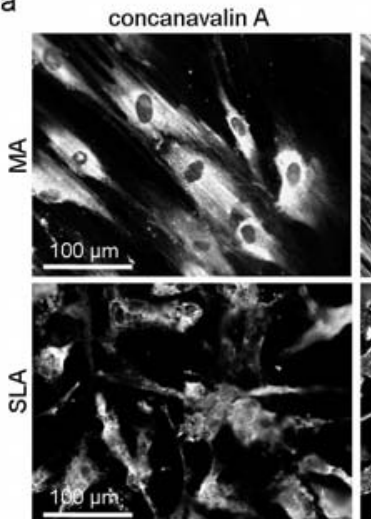

c

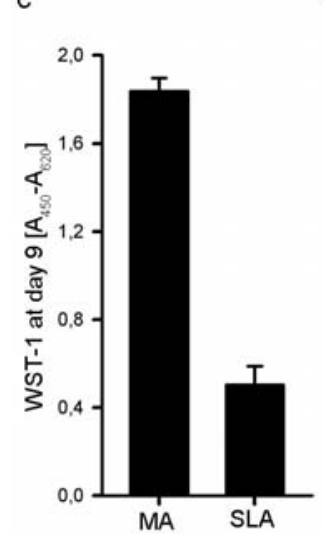

d

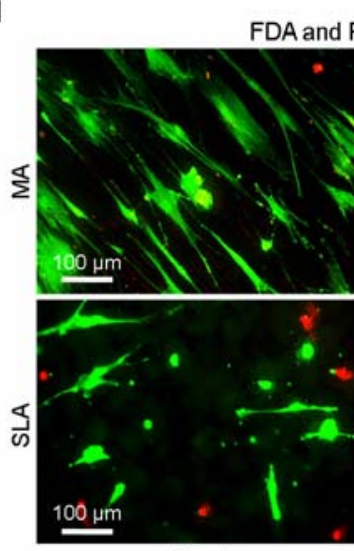

day 1 phalloidin

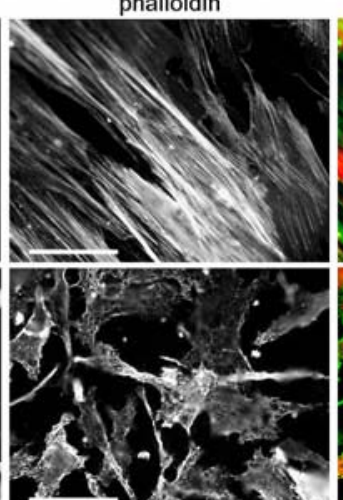

FDA and PI staining

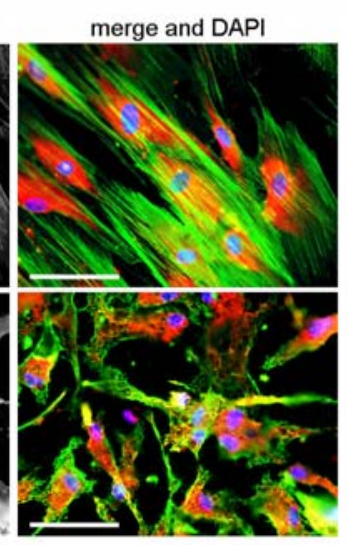

b

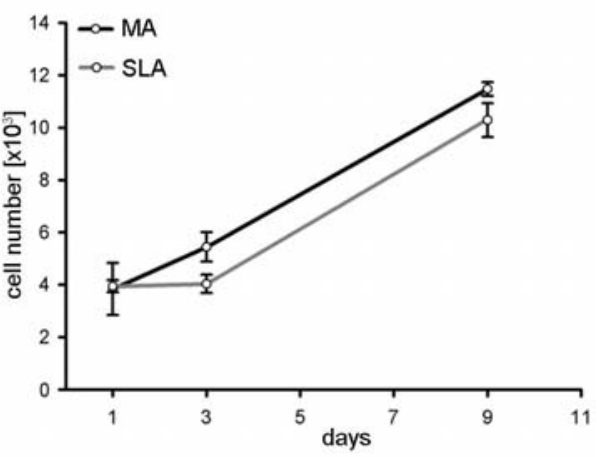

e
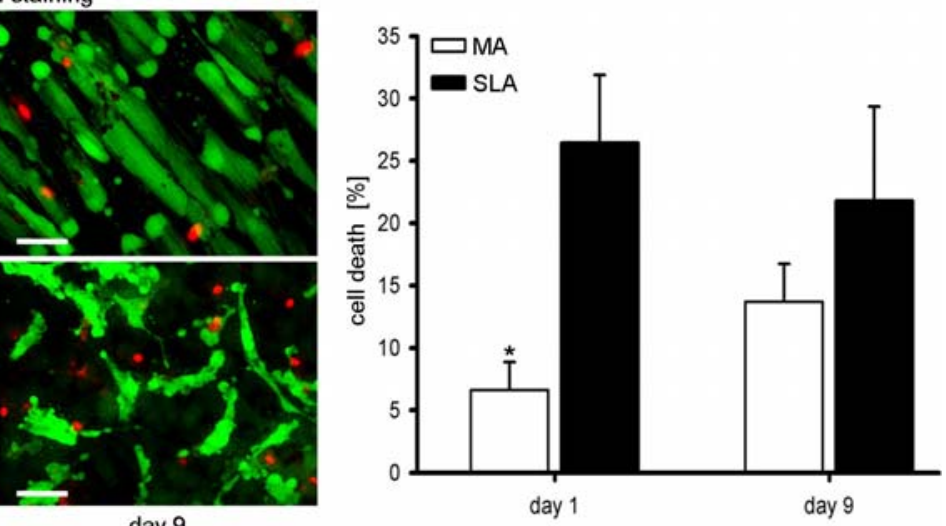

Fig. 6. Analysis of PDL-hTERT cell behaviour on the titanium scaffolds. (a) Membrane (concanavalin A) and actin (phalloidin) stainings show different cell morphology and actin organization on MA and SLA. (b) Determination of cell growth by nuclear counting. Despite similar expansion rate after day 3, higher cell numbers were obtained on the MA than on the SLA. (c) WST-1 cell proliferation assay at day 9 confirmed that PDL-hTERT cells have higher proliferation/metabolic activity on MA surface. (d) Investigation of cell death by live-dead assay (live, fluoresceindiacetat (FDA)-positive cells in green; dead, propidiumiodid (PI)-positive cells in red). (e) Quantification of dead cells, obtained at day 1 and 9 . The amount of dead cells was consistently lower on MA than on SLA (day $1 p=$ 0.0417). Two independent scaffold seedings were used for the calculations in (b), (c) and (e).

been found on a variety of cells, including MSC. PDLhTERT cells show no expression of CD45, a typical $\mathrm{T}$ and $\mathrm{B}$ cell antigen used as a negative marker (Table. 2).

In Fig. 5a RT-PCR results for several tendon-, bone-, and extracellular matrix-related genes are shown. PDL and PDL-hTERT cells demonstrated strong expression of Scleraxis, tenascin C, Runx 2, collagen 1 and 3, weak expression of tenomodulin and no expression of bone sialo protein (BSP).

PDL cells have been shown to differentiate into osteoblasts or cementoblasts and therefore, it was tested whether the presence of the hTERT-transgene affects PDL osteogenic differentiation. As shown by Alizarin Red staining (Fig. 5b), the primary as well as the hTERTtransduced PDL cells produced abundantly calcified matrix after 21 days of stimulation.

\section{PDL-hTERT cell spreading, growth and survival on} MA and SLA scaffolds

PDL-hTERT cell spreading and actin organization was compared on both scaffold types (Fig. 6a). On the MA, PDL-hTERT cells arranged themselves in parallel rows and retained their typical elongated shape. Furthermore, their actin fibres were very robust and longitudinally
Table 2. FACS analyses of surface antigen expression of PDL-hTERT

Positive cells

Surface antigens

$\begin{array}{ll}\text { CD13 (Aminopeptidase N) } & 99.1 \pm 0.07 \\ \text { CD29 (Integrin } \beta 1) & 98.8 \pm 0.22 \\ \text { CD44 (Hyaluronan receptor) } & 4.7 \pm 0.21 \\ \text { CD45 (Leukocyte common antigen) } & 0.5 \pm 0.23 \\ \text { CD73 (Ecto-5'-nucleotidase) } & 92.9 \pm 0.72 \\ \text { CD90 (Thy-1) } & 96.6 \pm 0.92 \\ \text { CD105 (Endoglin) } & 95.4 \pm 0.49\end{array}$

The data represent the mean value and standard deviation of three independent FACS experiments. PDLhTERT cells in 58-66 PD were analysed. 
a

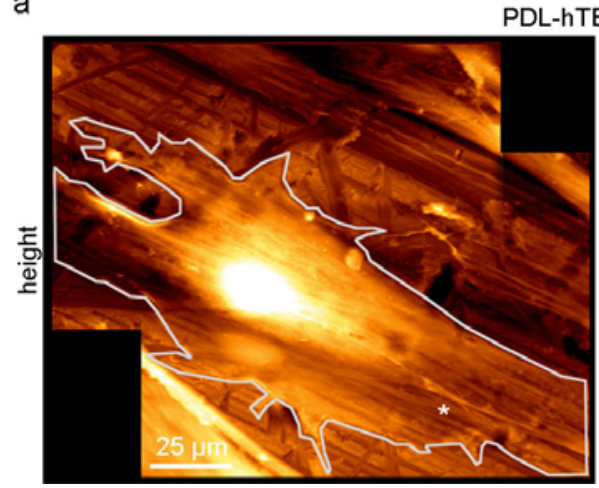

PDL-hTERT on MA

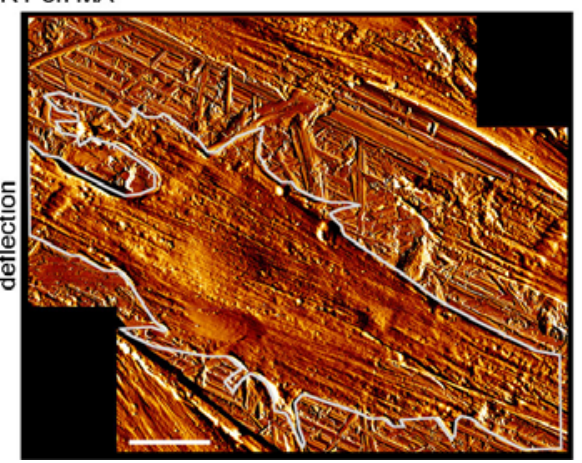

b

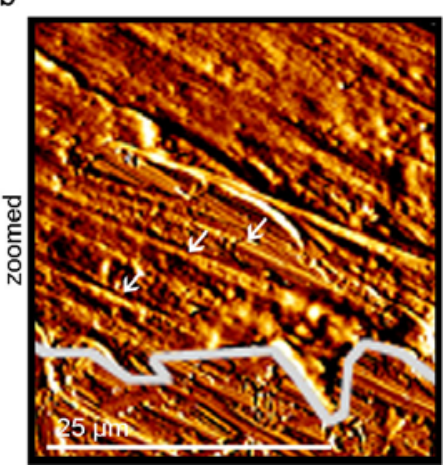

Fig. 7. AFM micrographs of PDL-hTERT cells grown on MA. (a) Height and deflection images of a single PDLhTERT cell. The cell border is outlined in gray. The star in (a) designates the cell area that is magnified in (b). The cell body and the actin fibres (indicated with white arrows) are aligned longitudinally to the MA micro-ridges.

MA

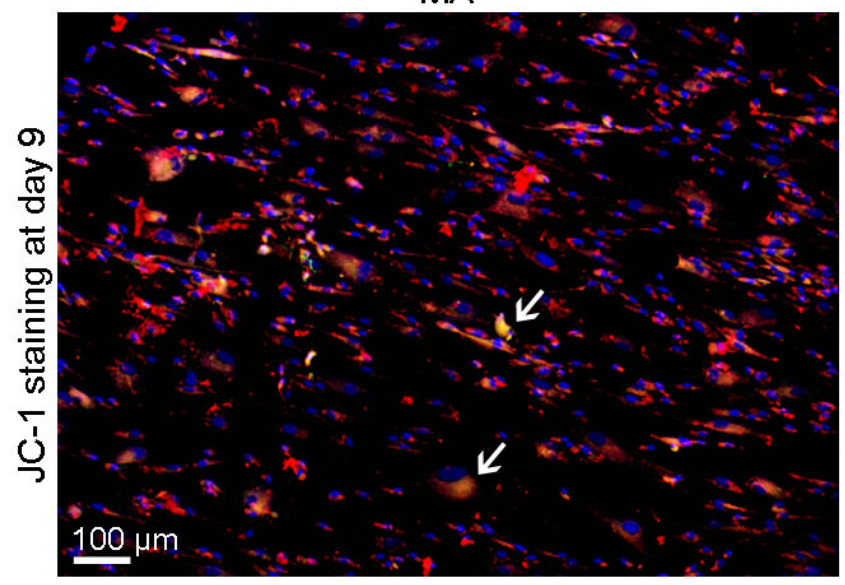

\section{SLA}

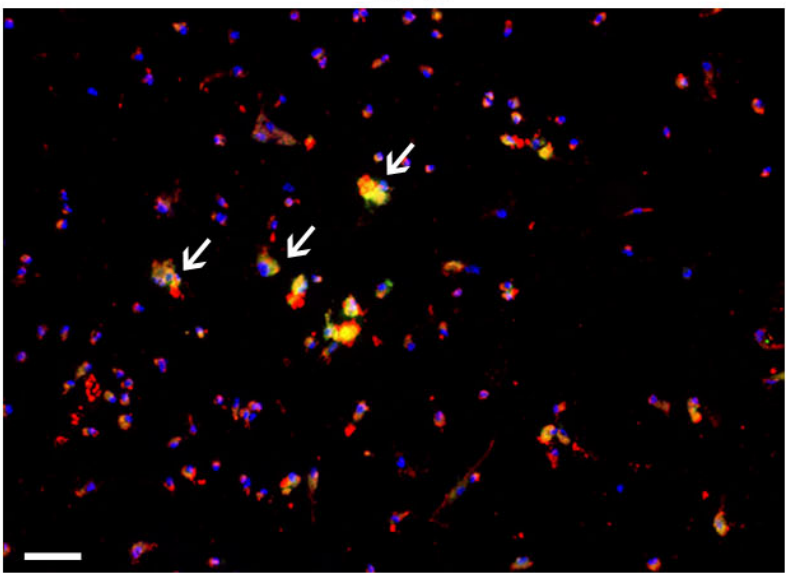

Fig. 8. JC-1 staining of PDL-hTERT cells grown on both scaffolds for 9 days. JC-1 aggregates and emits red colour in cells with intact mitochondria whereas in apoptotic cells, due to mitochondrial membrane leakage, JC-1 is released as a monomer in the cytoplasm labelling the cells in green/yellow (white arrows). Several apoptotic cells are visible on the SLA surface despite the low cell confluence.

deposited. Interestingly, the cell rows, as well as the actin fibres, aligned alongside to the parallel micro-ridges of the MA titanium (Fig. 7). On the SLA, PDL-hTERT cells were dispersed and had very irregular, mostly triangular, shapes. The actin skeleton was formed from much shorter actin bundles that were arranged in a net-like structure.

The cell propagation on MA and SLA was estimated by nuclear counting over 9 days (Fig. 6b). PDL-hTERT cells expanded on both scaffolds; however, they reached higher cell numbers at day $3\left(5.5 \pm 0.5 \times 10^{3}\right.$ cells $)$ and day $9\left(11.5 \pm 0.3 \times 10^{3}\right.$ cells $)$ on the MA. Regarding the SLA, PDL-hTERT cells had a delay in proliferation between day $1\left(3.9 \pm 0.2 \times 10^{3}\right.$ cells $)$ and $3\left(4.0 \pm 0.3 \times 10^{3}\right.$ cells $)$, but after day 3 the growth rate was similar to MA and by day 9 the cell number reached $9.2 \pm 0.6 \times 10^{3}$. In order to verify the observed growth deficit of PDL-hTERT cells on the SLA, an additional experiment using a WST-1 cell proliferation assay was performed at day 9 (Fig. 6c). The WST-1 results confirmed that PDL-hTERT cells have higher metabolic/ proliferative activity (3.7-fold) on MA than on SLA.

Next, we investigated the extent of cell death on both scaffold types. In Fig. 6d and e, representative images of FDA and PI staining are shown, together with the quantification of dead cells. At day 1, the amount of dead cells was 4-fold higher on SLA than on MA. At day 9, a 2- fold increase in the amount of dead cells was observed on the MA scaffolds but at the same time point the cell confluence reached approx. 90\%. In contrast, on SLA, PDL-hTERT cells had approx. 50\% confluence at day 9 and the amount of dead cells remained similar to that observed on day 1 . In order to confirm these results, a JC1 staining, which discriminates cells in early apoptosis, was additionally performed at day 9 . Apoptotic cells were detected on both surface types; however, the cell confluence was different between MA and SLA, approx. $90 \%$ and $50 \%$, respectively (Fig. 8).

\section{Osteogenic differentiation of PDL-hTERT cells on MA and SLA scaffolds}

PDL-hTERT cells were osteogenically stimulated for 21 days. Thereafter, Alizarin red staining (Fig. 9a) and quantification (Fig. 9b) were used to compare the degree of osteogenic differentiation on MA and SLA. The results demonstrated that between both scaffold types, MA showed the highest Alizarin Red values, which was 4-times higher than that observed on SLA. Finally, in order to investigate whether the significantly lower Alizarin Red level on SLA is due to a higher cell death rate compared to MA, a live-dead assay was performed at day 21 (Fig. 9c). The amount of dead cells on SLA was $106 \pm 12.8 \times 10^{3}$ 
a

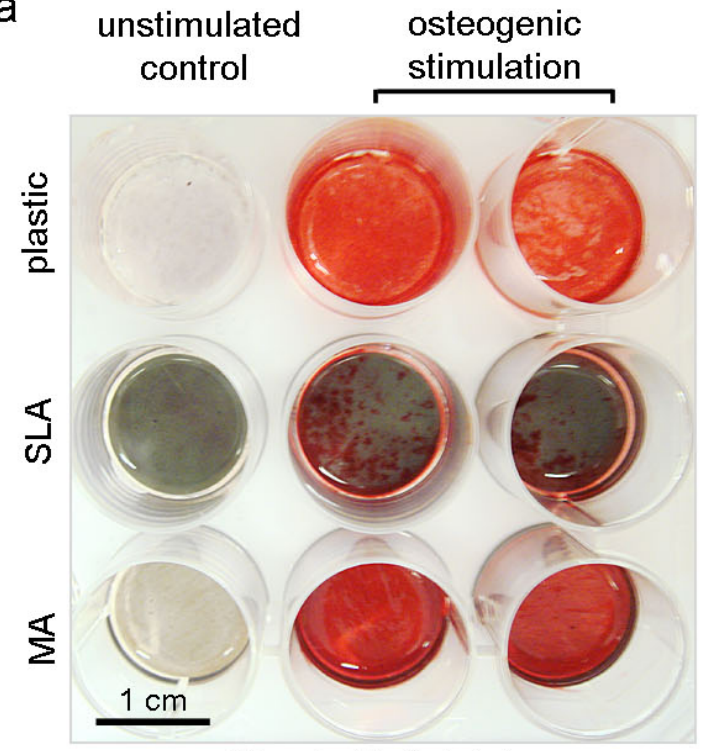

Alizarin Red staining

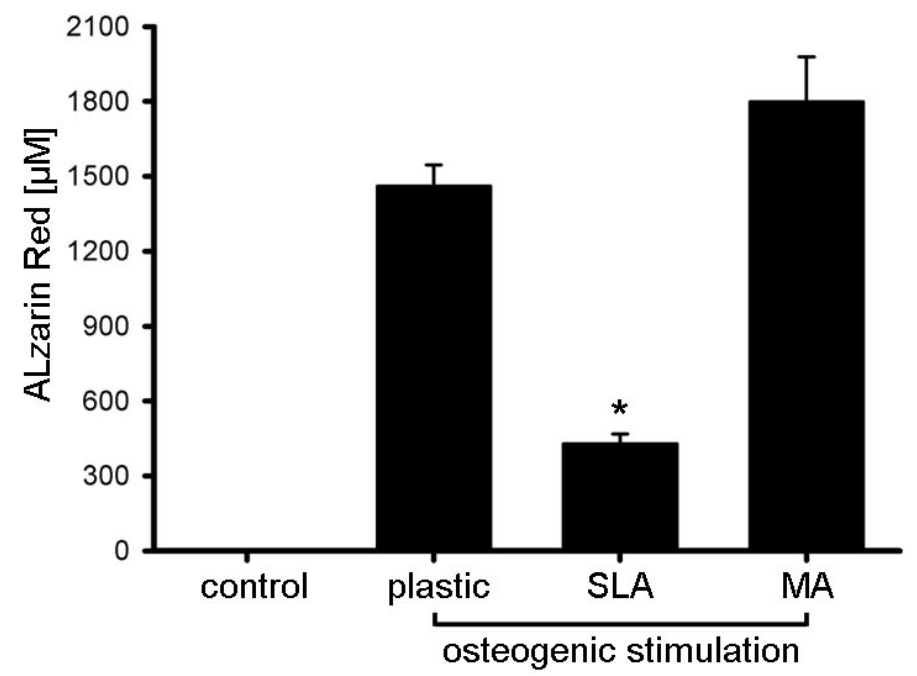

$\mathrm{C}$
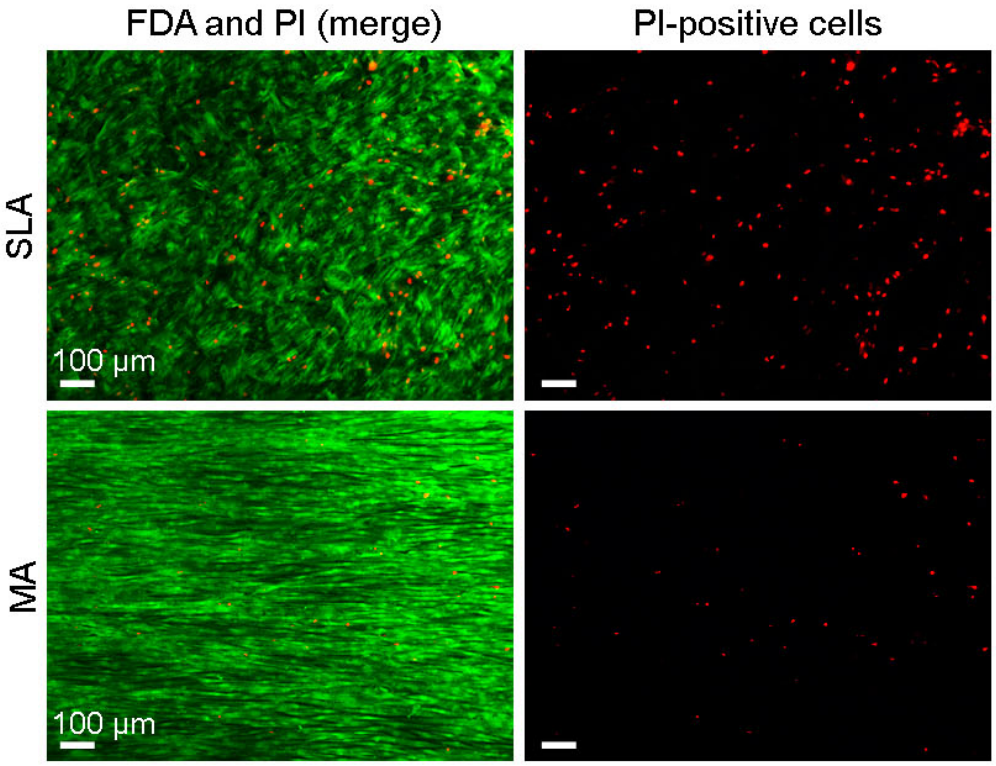

d

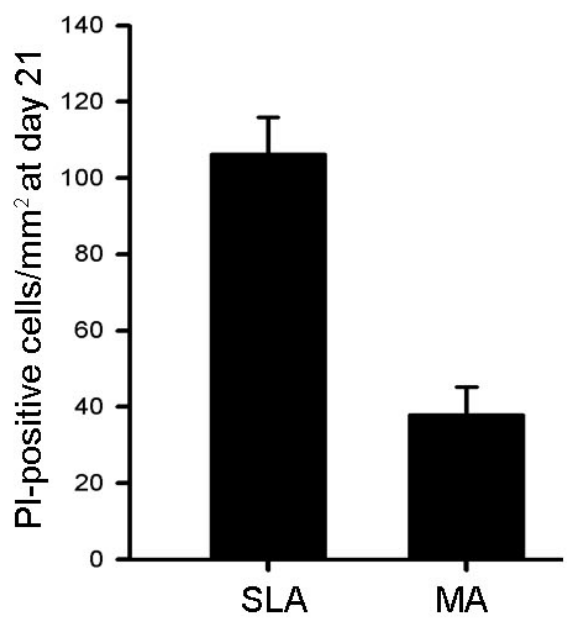

Fig. 9. Osteogenic stimulation of PDL-hTERT cells ( 82 PD) on both scaffold types examined by Alizarin red staining (a) and quantification (b). PDL-hTERT cells differentiated similarly well on MA and plastic (positive control) whereas the calcification on SLA was significantly lower ( $p=0.0090$, versus MA scaffold). The osteogenic stimulation was performed twice independently as each experiment consisted of duplicates. Live-dead assay (c) and quantification (d) of PI-positive (dead) cells at day 21 showed 2.7-fold higher cell death rate on SLA than on MA.

cells $/ \mathrm{mm}^{2}$. In contrast on MA, the PI-positive cells were only $38 \pm 15 \times 10^{3}$ cells $/ \mathrm{mm}^{2}$ (Fig. 9d).

\section{Discussion}

Due to the potential application of PDL-derived cells in therapy of periodontitis and post-traumatic PDL reconstruction, we first aimed to create a novel, immortalized PDL cell line via lentiviral gene transfer of hTERT. We have recently reported the successful immortalization of human MSC by lentiviral delivery of hTERT (SCP-1 cell line). These cells showed unlimited growth, but no sign of malignant transformation in vitro or in vivo (Böcker et al., 2008). In contrast to papilloma or retroviruses, which have been previously used for cell immortalization, lentiviral vectors have different integration-site patterns and are less prone to transcriptional silencing ( Pfeifer et al., 2002; Kohn et al., 2007). Moreover, the first reported clinical trial with lentivirus demonstrated the efficient and safe delivery of synthetic anti-HIV genes into patient T cells (Levine et al., 2006). Therefore, the same viral approach was used here to obtain a PDL-hTERT cell line. As a result of the immortalization, PDL-hTERT cells demonstrated stable proliferation in vitro as well as a phenotype similar to the primary cells. FACS and PCR analyses showed that PDL-hTERT cells expressed MSC-related surface antigens, Scleraxis and tenomodulin mRNA. Tenomodulin is predominantly expressed in tendons and ligaments, and as such it serves as a useful gene marker for these tissues (Docheva et al., 
2005). The cells also expressed the osteogenic-related marker Runx2 but not BSP. Furthermore, upon stimulation, PDL-hTERT cells were able to differentiate into osteoblasts. Thus, we can conclude that the PDL-hTERT cells are progenitors and are suitable cell line is for further periodontitis- and PDL-engineering-related studies.

Next, we aimed to determine what kind of substrate surface organization and roughness is optimal for this cell type. Therefore, PDL-hTERT cells were cultivated on substrates with two different surface textures - smooth (MA) and rough (SLA) titanium. First, their cell spreading, growth and survival were evaluated. PDL-hTERT cells showed increased spreading and vitality on MA surface while on SLA the cells had altered cell shapes, slower growth and higher death rates. Upon prolonged cell cultivation, the number of dead cells increased on both scaffolds due to the formation of confluent cell layers. However, on SLA, the number of PI-positive cells was higher than on MA. Finally, since PDL progenitors can differentiate into osteoblasts - a process that might contribute to cementum formation in vivo, we osteogenically stimulated PDL-hTERT cells on each surface type. In our experiments, PDL-hTERT cells differentiated to a similar extent on the smooth surfaces (MA and plastic) while on the rough surface (SLA), this cell type differentiated significantly less. This might be a consequence of the reduced cell spreading, growth and survival on SLA.

Overall, the above findings are in contrast to the reported behaviour of osteoblast-like cells. Several studies have shown that SLA not only enhanced the attachment and differentiation of osteoblast, MG63 and bone marrowderived cells, but also led to increased bone apposition in vivo ( Buser D, 2001; Lumbikanonda et al., 2001; Boyan et al., 2003; Karageorgiou et al., 2005; Kim et al., 2006; Shibli et al., 2007; Ricci et al., 2008). Furthermore, a recent study with stem cells derived from the dental pulp has reported better and quicker osteogenic differentiation when the cells were challenged with even rougher, laser-sintered titanium surface vs. just acid-etched titanium (Mangano et al., 2010). Interestingly, Wall et al., 2009 showed that similarly to our data, MSC from the bone marrow proliferated better on smooth titanium but nevertheless showed an increased matrix mineralization on rough titanium. Our results, however, are in line with studies dealing with gingival fibroblasts and chondrocytes, cell types exhibiting also superb morphology and proliferation on smoother titanium (Oates et al., 2005). Additionally, in a recent publication by Hacking et al., 2008 several cell types - MC3T3, TF274 (MSC cell line), murine femoral stromal cells and canine bone marrow cells were investigated and cell type-specific differences were observed. For example, the MC3T3, TF274 and murine femoral stromal cells, in contrast to the canine-derived cells, proliferated and osteogenically differentiated better on plastic and polished titanium than on irregularly textured titanium. Moreover, Kramer et al., 2009, who analysed PDL cell adhesion on various titanium implants and the involvement of integrin beta 1 , demonstrated that the attachment of this cell type is much higher on polished than on SLA titanium.
Hence, we can suggest that the difference in the osteogenic differentiation of bone marrow- or dental pulpderived stem cells and PDL-derived progenitors might be due to differences in the cell types and their origin. Therefore, the cell-type specific response has to be carefully considered during the evaluation of novel periodontal and dental tissue engineering models. Finally, the observation that PDL-derived cells have improved spreading, propagation and survival on a surface composed of parallel, approx. $3 \mu \mathrm{m}$ high ridges and with a RMS roughness lower than $0.5 \mu \mathrm{m}$ can be useful in the design of scaffold or membrane surfaces that are purposed for therapy of moderate or severe periodontitis.

\section{Conclusions}

Using lentiviral transduction of hTERT, a new, immortalized PDL-derived cell line was obtained. PDLhTERT cells had an extended lifespan and exhibited a phenotype similar to PDL progenitor cells. When cultivated on different titanium textures, this cell type behaved differently to osteoblast-like cells, as PDL-hTERT cells had augmented spreading, vitality and matrix calcification on smooth rather than on rough surfaces. Taken together, we propose PDL-hTERT cells as a useful cell line for periodontitis-related research and development of novel applications in PDL regeneration.

\section{Acknowledgements}

D.D. and M. S. acknowledge the support of the AO Research Fund of the AO Foundation (Project No. S-0718D) and the FöFoLe Research Program of the Medical Faculty of the Ludwig-Maximilians-University (Project No. 37/2006); D. P. and H. C.-S. acknowledge the support of the German Excellence Initiative via the "Nanosystems Initiative Munich (NIM)". We thank Dr. M. Wieland from Straumann, Switzerland for providing the titanium scaffolds; Dr. S. Otto for helpful discussion; M. Kaiser for support with the white-light confocal microscope and Prof. W. Mutschler for his constant support of the research laboratory. Parts of this study have been presented in posters at the $2^{\text {nd }}$ International Symposium on Biotechnology in Musculoskeletal Repair (Lausanne 2008, Switzerland) and at the ECM X: Stem cells for musculoskeletal regeneration (Davos 2009, Switzerland), both sponsored by the AO Foundation.

\section{References}

Bluteau G, Luder HU, De Bari C, Mitsiadis TA (2008) Stem cells for tooth engineering. Eur Cell Mater 16: 1-9.

Böcker W, Rossmann O, Docheva D, Malterer G, Mutschler W, Schieker M (2007) Quantitative polymerase chain reaction as a reliable method to determine functional lentiviral titer after ex vivo gene transfer in human mesenchymal stem cells. J Gene Med 9: 585-595. 
Böcker W, Yin Z, Drosse I, Haasters F, Rossmann O, Wierer M, Popov C, Locher M, Mutschler W, Docheva D, Schieker M (2008) Introducing a single-cell-derived human mesenchymal stem cell line expressing hTERT after lentiviral gene transfer. J Cell Mol Med 12: 1347-1359.

Boyan BD, Lossdorfer S, Wang L, Zhao G, Lohmann CH, Cochran DL, Schwartz Z (2003) Osteoblasts generate an osteogenic microenvironment when grown on surfaces with rough microtopographies. Eur Cell Mater 6: 22-27.

Buser D (2001) Titanium for dental application. In: Brunette DM, Tengvall P, Textor M (eds) Titanium in medicine: material science, surface science, engineering, biological responses and medical applications. Springer, Berlin, pp 875-888

Docheva D, Hunziker EB, Fassler R, Brandau O (2005) Tenomodulin is necessary for tenocyte proliferation and tendon maturation. Mol Cell Biol 25: 699-705.

Docheva D, Popov C, Mutschler W, Schieker M (2007) Human mesenchymal stem cells in contact with their environment: surface characteristics and the integrin system. J Cell Mol Med 11: 21-38.

Docheva D, Haasters F, Schieker M (2008) Mesenchymal stem cells and their cell surface receptors. Curr Rheumatol Rev 4: 155-160.

Fujii S, Maeda H, Wada N, Tomokiyo A, Saito M, Akamine A (2008) Investigating a clonal human periodontal ligament progenitor/stem cell line in vitro and in vivo. J Cell Physiol 215: 743-749.

Fujita T, Otsuka-Tanaka Y, Tahara H, Ide T, Abiko Y, Mega J (2005) Establishment of immortalized clonal cells derived from periodontal ligament cells by induction of the hTERT gene. J Oral Sci 47: 177-184.

Hacking SA, Harvey E, Roughley P, Tanzer M, Bobyn $\mathrm{J}$ (2008) The response of mineralizing culture systems to microtextured and polished titanium surfaces. J Orthop Res 26: 1347-1354.

Huang GT, Shagramanova K, Chan SW (2006) Formation of odontoblast-like cells from cultured human dental pulp cells on dentin in vitro. J Endod 32: 10661073.

Itaya T, Kagami H, Okada K, Yamawaki A, Narita Y, Inoue M, Sumita Y, Ueda M (2009) Characteristic changes of periodontal ligament-derived cells during passage. J Periodontal Res 44: 425-433.

Ivanovski S, Gronthos S, Shi S, Bartold PM (2006) Stem cells in the periodontal ligament. Oral Dis 12: 358363 .

Karageorgiou V, Kaplan D (2005) Porosity of 3D biomaterial scaffolds and osteogenesis. Biomaterials 26: 5474-5491.

Kim MJ, Kim CW, Lim YJ, Heo SJ (2006) Microrough titanium surface affects biologic response in MG63 osteoblast-like cells. J Biomed Mater Res A 79: 1023-1032.

Kohn DB (2007) Lentiviral vectors ready for primetime. Nat Biotechnol 25: 65-66.

Kramer PR, Janikkeith A, Cai Z, Ma S, Watanabe I (2009) Integrin mediated attachment of periodontal ligament to titanium surfaces. Dent Mater 25: 877-883.

Levine BL, Humeau LM, Boyer J, MacGregor RR, Rebello T, Lu X, Binder GK, Slepushkin V, Lemiale F, Mascola JR, Bushman FD, Dropulic B, June CH (2006)
Gene transfer in humans using a conditionally replicating lentiviral vector. Proc Natl Acad Sci U S A 103: 1737217377.

Lumbikanonda N, Sammons R (2001) Bone cell attachment to dental implants of different surface characteristics. Int J Oral Maxillofac Implants 16: 627636.

Mangano C, De Rosa A, Desiderio V, d'Aquino R, Piattelli A, De Francesco F, Tirino V, Mangano F, Papaccio G (2010) The osteoblastic differentiation of dental pulp stem cells and bone formation on different titanium surface textures. Biomaterials 31: 3543-3551.

Oates TW, Maller SC, West J, Steffensen B (2005) Human gingival fibroblast integrin subunit expression on titanium implant surfaces. J Periodontol 76: 1743-1750.

Parlar A, Bosshardt DD, Unsal B, Cetiner D, Haytac C, Lang NP (2005) New formation of periodontal tissues around titanium implants in a novel dentin chamber model. Clin Oral Implants Res 16: 259-267.

Pfeifer A, Ikawa M, Dayn Y, Verma IM (2002) Transgenesis by lentiviral vectors: lack of gene silencing in mammalian embryonic stem cells and preimplantation embryos. Proc Natl Acad Sci U S A 99: 2140-2145.

Pi SH, Lee SK, Hwang YS, Choi MG, Lee SK, Kim EC (2007) Differential expression of periodontal ligamentspecific markers and osteogenic differentiation in human papilloma virus 16-immortalized human gingival fibroblasts and periodontal ligament cells. J Periodontal Res 42: 104-113.

Ricci JL, Grew JC, Alexander H (2008) Connectivetissue responses to defined biomaterial surfaces. I. Growth of rat fibroblast and bone marrow cell colonies on microgrooved substrates. J Biomed Mater Res A 85: 313325.

Rupp F, Scheideler L, Olshanska N, de Wild M, Wieland M, Geis-Gerstorfer J (2006) Enhancing surface free energy and hydrophilicity through chemical modification of microstructured titanium implant surfaces. J Biomed Mater Res A 76: 323-334.

Seo BM, Miura M, Gronthos S, Bartold PM, Batouli S, Brahim J, Young M, Robey PG, Wang CY, Shi S (2004) Investigation of multipotent postnatal stem cells from human periodontal ligament. Lancet 364: 149-155.

Shi S, Bartold PM, Miura M, Seo BM, Robey PG, Gronthos S (2005) The efficacy of mesenchymal stem cells to regenerate and repair dental structures. Orthod Craniofac Res 8: 191-199.

Shibli JA, Grassi S, de Figueiredo LC, Feres M, Marcantonio E Jr, Iezzi G, Piattelli A (2007) Influence of implant surface topography on early osseointegration: a histological study in human jaws. J Biomed Mater Res B Appl Biomater 80: 377-385.

Tomokiyo A, Maeda H, Fujii S, Wada N, Shima K, Akamine A (2008) Development of a multipotent clonal human periodontal ligament cell line. Differentiation 76: 337-347.

Wall I, Donos N, Carlqvist K, Jones F, Brett P (2009) Modified titanium surfaces promote accelerated osteogenic differentiation of mesenchymal stromal cells in vitro. Bone 45: 17-26. 


\section{Discussion with Reviewer}

Reviewer II: Please explain why your results completely disagree with all the previous ones already published. Explain adequately the possible understandable reasons. Authors: The present study concluded that the PDL cell type favours smoother surfaces such as MA over SLA titanium. The PDL cellular preferences are indeed opposite to osteoblast-like cells (osteoblasts, bone marrow MSC) and in this respect the results are controversial, but our results go well in line with the behaviour of other cell types such as gingival fibroblasts and chondrocytes. These cells, similarly to PDL-derived cells, have been reported to attach and expand better on smoother rather than on rougher surfaces. In brief, there is a cell type-specific behaviour on the differently structured materials, which should be considered in the evaluation of different materials as well as in the design of novel tissue engineering strategies. In other words, the field should try not to choose "one size fits all" label and carefully explore the responses of different cell types that may encounter the materials in vivo. Our study indicates that significant differences can exist among cell types in vitro and moreover, it should be kept in mind that these differences might be further pronounced when cell-loaded scaffolds are analysed in vivo.

Reviewer II: What clinical advantages could MA confer over SLA titanium scaffolds, when employing a PDLbased tissue engineering approach?
Authors: We reported that PDL-derived cells have augmented growth and survival rates on smooth surface such as MA. With regards to PDL engineering, this finding can be used for the design and development of novel surfaces. A clinical advantage of smooth surfaces is their low bacterial ingrowths that can be a very beneficial implant feature in treatment of periodontitis or perimplantitis, which are bacterial-triggered conditions. However, in order to properly evaluate the clinical advantage of a particular tissue engineering set up, adequate pre-clinical studies have to be carried out, for example applying PDL-loaded existent scaffolds or novel materials in periodontitis or jaw-defect in vivo models.

Reviewer II: Do the authors really think that bone production of a good quality and enough quantity can be achieved on a smooth surface rather than a concave surface?

Authors: In our study, we observed that PDL cells were able to osteogenically differentiate on smooth as well as on rough surface. The quantitative analysis showed that PDL cells produced more calcified matrix on the smooth surface and we proposed that this is in consequence of the enhanced spreading and survival specific to this cell type. With regards to implant osteointegration, we think that in the last years numerous studies have delivered convincing data that rough surfaces give the best results, compared with smooth ones. 